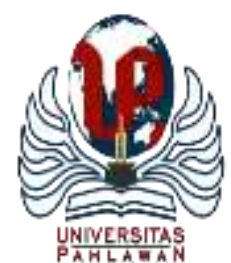

\title{
JURNALBASICEDU
}

Volume 6 Nomor 1 Tahun 2022 Halaman 692 - 699

Research \& Learningin Elementary Education https://jbasic.org/index.php/basicedu

\section{Penerapan Model Pembelajaran Inkuiri Terbimbing untuk Meningkatkan Hasil Belajar Siswa}

\author{
Yosi Shandra $^{1 凶}$, Mega Adyna Movitaria ${ }^{2}$ \\ Guru, SMA Negeri 10 Padang $^{1}$, Indonesia \\ Pendidikan Guru Madrasah Ibtidaiyah, Institut Agama Islam Sumatera Barat, Indonesia ${ }^{2}$ \\ E-mail: yosishandra@gmail.com ${ }^{1}$, megaadyna.iaisumbar@gmail.com²
}

\begin{abstract}
Abstrak
Peserta didik telah memiliki mindset awal bahwa pembelajaran akuntansi sulit dipahami. Sebagian besar peserta didik malas untuk diajak berpikir apalagi pada level analisis. Hal ini tergambar dari sikap pasif, apatis, kurang peduli dan masa bodoh yang terlihat dari peserta didik. Tujuan penelitian ini adalah untuk mengetahui peningkatan aktivitas dan hasil belajar akuntansi peserta didik melalui penerapan model pembelajran inkuiri terbimbing. Metode penelitian yang digunakan adalah Penelitian tindakan kelas. Dengan subjek penelitian adalah siswa kelas XII MIPA 2. Analisis Data yang digunakan adalah lembar observasi dan tes. Hasil penelitian menunjukkan bahwa terjadi peningkatan aktivitas belajar peserta didikdari siklus I dengan persentase $19 \%$, sementara Siklus II dengan persentase $94 \%$. Pada siklus I diperoleh $31 \%$ yang tuntas dengan nilai ratarata 63, selanjutnya pada siklus II diperoleh $84 \%$ yang tuntas dengan nilai rata-rata 83 . Sehingga dapat diketahui peningkatan nilai rata-rata dari siklus I ke siklus II sebesar 53\%. Jadi dapat disimpulkan bahwa penerapan model pembelajaran inkuiri terbimbing dapat meningkatkan hasil belajar akuntansi peserta didik.

Kata Kunci: Model Inkuiri Terbimbing, hasil belajar, akuntasi.
\end{abstract}

\begin{abstract}
Students already have the initial mindset that accounting learning is difficult to understand. Most students are too lazy to be invited to think, especially at the level of analysis. This is illustrated by the passive attitude, apathy, lack of care, and ignorance seen from students. The purpose of this study was to determine the increase in students' accounting learning activities and outcomes through the application of the guided inquiry learning model. The research method used is classroom action research. The research subjects were students of class XII MIPA 2. Analysis The data used were observation sheets and tests. The results showed that there was an increase in student learning activities from cycle I with a percentage of $19 \%$, while Cycle II with a percentage of $94 \%$. In the first cycle, $31 \%$ were completed with an average score of 63, then in the second cycle, $84 \%$ were completed with an average score of 83. So it can be seen that the increase in the average value from cycle I to cycle II was 53\%. So it can be concluded that the application of the guided inquiry learning model can improve students' accounting learning outcomes.
\end{abstract}

Keywords: Guided Inquiry Model, learning outcomes, accounting.

Copyright (c) 2022 Yosi Shandra, Mega Adyna Movitaria

$\triangle$ Corresponding author :

Email : yosishandra@gmail.com

DOI : https://doi.org/10.31004/basicedu.v6i1.2006

ISSN 2580-3735 (Media Cetak)

ISSN 2580-1147 (Media Online)

Jurnal Basicedu Vol 6 No 1 Tahun 2022

p-ISSN 2580-3735 e-ISSN 2580-1147 


\section{PENDAHULUAN}

Guru merupakan unsur terpenting dalam proses pembelajaran. Saat peran orang tua sebagai pendidik di rumah digantikan oleh peran guru disekolah, maka tuntutan kemampuan pedagogis akan beralih kepada guru (Jamin, 2018). Karena tidak hanya sebagai pengajar yang mentransfer ilmu pengetahuan dan keterampilan kepada peserta didik, tetapi juga sebagai pendidik dan pembimbing yang membantu peserta didik untuk mengembangkan segala potensi terutama terkait dengan potensi akademis maupun non akademis. Guru sebagai tenaga profesional memiliki sejumlah kemampuan mengaplikasikan berbagai teori belajar dalam bidang pengajaran, menerapkan metode pembelajaran yang efektif dan efisien, sehingga dalam mewujudkan kuantitas dan kualitas pembelajaran di kelas, guru dituntut mampu menggunakan pendekatan, strategi, metode dan model pembelajaran dalam setiap proses pembelajaran (Mulyana, 2010).

Menurut Darlis \& Movitaria, (2021) model pembelajaran merupakan kerangka konseptil yang melukiskan prosedur yang sistematis dalam mengorganisasikan pengalaman belajar untuk mencapai tujuan belajar tertentu, dan berfungsi sebagai pedoman bagi para perancang pembelajaran dan para guru untuk merencanakan dan melaksanakan aktivitas pembelajaran. Guru harus memiliki keterampilan dalam memilih model pembelajaran yang tepat sesuai dengan materi yang akan di sampaikan, guru harus memperhatikan keadaan dan kondisi peserta didik, bahan pelajaran serta sumber belajar yang ada agar penggunaan model pembelajaran dapat diterapkan secara efektif dan menunjang keberhasilan belajar peserta didik (Movitaria \& Shandra, 2020). Guru bukan hanya menguasai materi, tetapi guru harus bisa menyampaikan materi kepada peserta didik agar mereka dapat memahami, menyerap dan menalar materi apa yang sedang diajarkan. Dalam konteks tersebut guru harus menerapkan metode yang tepat pada materi yang pembelajaran, khususnya pembelajaran ekonomi.

Sebagai bagian dari mata pelajaran ekonomi, akuntansi merupakan pelajaran yang dipelajari pada kelas XII baik pada kelas peminatan maupun kelas lintas minat. Pada pembelajaran akuntansi, peserta didik dapat mengetahui dan memahami konsep dasar akuntansi, menerapkan konsep dasar tersebut untuk menyusun siklus dasar akuntansi serta memiliki kemampuan dalam mengolah data keuangan untuk menghasilkan informasi keuangan (Nurudin, 2020). Selanjutnya dengan keterampilan tersebut peserta didik diharapkan dapat menguasai serta mengaplikasikan konsep akuntansi dalam kehidupan sehari-hari.

Pada pembelajaran akuntansi, guru harus terampil dalam menanamkan konsep awal pada peserta didik, sehingga peserta didikpun dituntut untuk memiliki pemahaman yang cukup disertai dengan keterampilan yang dapat menunjang ketercapaian kompetensi yang telah ditetapkan (Djo, 2021). Oleh karena pembelajaran akuntansi merupakan pembelajaran yang baru bagi peserta didik, guru harus mampu menciptakan situasi pembelajaran yang hidup dan memicu motivasi peserta didik agarbisa belajar secara aktif dan optimal, dengan kata lain pembelajaran berpusat pada peserta didik, sedangkan guru hanya bertindak sebagai fasilitator dan motivator dalam mengoptimalkan pembelajaran (Darmadi, 2017).

Berdasarkan informasi yang diperoleh dari SMA Negeri 10 Padang, pembelajaran di sekolah sudah menerapkan kurikulum 2013 untuk semua jenjang pendidikan, baik kelas X, kelas XI,begitu juga dengan proses pembelajaran akuntansi di kelas XII. Adapun permasalahan yang masih umum pada sekolah tersebut adalah kurangnya perhatian peserta didik terhadap materi yang diberikan oleh guru. Pada dasarnya materi akuntansi merupakan pembelajaran yang baru mereka pelajari di kelas XII, sehingga peserta didik telah memiliki mindset awal bahwa pembelajaran akuntansi sulit dipahami. Sebagian besar peserta didik malas untuk diajak berpikir apalagi pada level C4 atau setara dengan level analisis pada materi pembelajaran. Hal ini tergambar dari sikap pasif, apatis, kurang peduli dan masa bodoh yang terlihat dari peserta didik. Dapat dipahami bahwa munculnya tanda-tanda rendahnya keterkaitan peserta didik terhadap suatu pelajaran, sumber kesalahnnya tidak hanya bersumber dari peserta didik, namun sangat dipengaruhi oleh seluruh komponen 
yang ada, baik pendidik, peserta didik, bahan ajar, proses belajar, tempat, waktu belajar dan kelengkapan sarana dan prasarana.

Fenomena yang sering juga terjadi di kelas adalah fenomena kejenuhan, dimana peserta didik merasa frustasi, sehingga pembelajaran tidak akan mendatangkan hasil yang maksimal. Kejenuhan belajar disebabkan oleh beberapa faktor. Pertama, faktor kesulitan bahan yang dipelajari meningkat, sehingga peserta didik tidak mampu menyelesaikan proses pembelajarannya. Kedua, metode pembelajaran yang digunakan tidak sesuai dengan karakteristik peserta didik, sehingga proses pembelajaran akan sia-sia. Ketiga, kejenuhan yang disebabkan oleh keletihan badan dan kelelahan (Movitaria \& Shandra, 2020). Faktor-faktor inilah yang menyebabkan kondisi pembelajaran yang ada di dalam kelas berjalan dengan kurang kondusif, sehingga dapat mempengaruhi aktivitas peserta didik di dalam kelas.

Aktivitas peserta didik merupakan sesuatu yang sangat penting dalam proses pembelajaran Aini et al., (2021). Peserta didik yang memiliki aktivitas positif akan memperoleh hasil belajar yang lebih baik dan sebaliknya, peserta didik yang memiliki aktifitas negatif akan memperoleh hasil belajar yang kurang memuaskan. Hasil belajar mempunyai peranan penting dalam proses pembelajaran. Proses penilaian terhadap hasil belajar dapat memberikan informasi kepada guru tentang kemajuan peserta didik dalam menguasai dan menyerap materi pembelajaran (Movitaria, 2017).

Aktivitas belajar akuntansi peserta didik masih sangat rendah yaitu dengan rata-rata perolehan persentase sebesar 33,96\% dari delapan aspek aktivitas yang diamati. Aspek tertinggi berada pada aspek menggambar (drawing aktivities) dengan persentase sebesar 62,50\%. Hal ini mengindikasikan bahwa sebesar $62,50 \%$ peserta didik telah membuat dan menggambar tabel persamaan akuntansi serta laporan keuangan dengan benar, sisanya masih ada yang melamun dan tidak bekerja, sedangkan aktivitas paling rendah terletak pada aspek motorik (motor activites),yaitu hanya sebesar 9,38\%. Hal ini disebabkan oleh peserta didik kurang aktif dan kurang kreatif dalam proses pembelajaran, sebagian besar hanya terpaku dengan laptop masingmasing dan materi yang ditayangkan guru pada slide power point.

Penilaian harian peserta didik kelas XII.MIPA 2 sangat memprihatinkan dengan persentase ketuntasan hanya sebesar $12,5 \%$ untuk KD pertama dan kedua, namun hal ini masih jauh dari apa yang diharapkan, sesuai dengan pendapat Latiana et al., (2018) untuk memperoleh hasil belajar yang baik, banyak faktor yang perlu diperhatikan. Secara garis besar faktor-faktor yang mempengaharui hasil belajar dapat digolongkan menjadi dua bagian yaitu faktor yang berasal dari dalam diri peserta didik (intern) yang teridiri dari faktor jasmani (kesehatan dan cacat tubuh) dan faktor psikologis (kecerdasan, konsentrasi, motivasi dan bakat). Sedangkan faktor yang berasal dari luar diri peserta didik (ekstern) terdiri dari faktor lingkungan keluarga, limgkungan sekolah dan lingkungan masyarakat. Kondisi tersebut diduga merupakan penyebab dari rendanya hasil belajar peserta didik.

Berdasarkan uraian di atas, perlu upaya untuk mengatasi segala permasalahan yang timbul dalam pembelajaran ekonomi terkhusus di bidang akuntansi pada kelas XII. Melihat kondisi dimana sangat pentingnya peran guru dalam rangka mengasah kemampuan berpikir peserta didik, mengoptimalkan aktivitas belajar dan meningkatkan hasil belajar maka diperlukanlah model, metode, strategi dan pendekatan pembelajaran yang tepat sehingga proses pembelajaran berjalan dengan efektif dan efisien demi meningkatkan aktivitas dan hasil belajar peserta didik (Pribadi, 2017). Model pembelajaran yang cocok dalam rangka mengatasi permasalahan ini adalah model pembelajaran inquiri terbimbing (guided inquiry). Model pembelajaran inkuiri terbimbing merupakan kegiatan pembelajaran yang melibatkan secara maksimal seluruh kemampuan peserta didik untuk mencari dan menemukan sesuatu secara sistematis, logis, kronologis, dan analitis sehingga dapat merumuskan sendiri penemuannya dengan penuh rasa percaya diri (Lovisia, 2018). Model pembelajaran inkuiri terbimbing merupakan proses pembelajaran yang menempatkan peserta didik untuk lebih banyak belajar mandiri dan mengembangkan kreativitas dalam pemecahan masalah sehingga 
peserta didik lebih banyak melakukan kegiatan sendiri atau dalam berkelompok untuk memecahkan masalah dengan bantuan guru (Wenno et al., 2016).

Penelitian ini sejalan dengan penelitian yang dilakukan oleh Diani et al., (2016) bahwa model pembelajaran inkuiri terbimbing dapat meningkatkan aktivitas pembelajaran peserta didik. Hasil penelitian menunjukkan bahwa aktivitas belajar peserta didik dari siklus pertama ke siklus kedua mengalami peningkatan sebesar 5,65\%, dari $61,02 \%$ pada siklus pertama ke $66,67 \%$ pada siklus kedua. Siklus kedua dan ketigapun juga mengalami peningkatan sebesar $16.66 \%$ dari $66,67 \%$ pada siklus kedua menjadi $88,83 \%$ pada siklus ketiga.

Penerapan model pembelajaran sangat perlu didukung dengan media pembelajaran yang mampu membantu peserta didik dalam rangka membangkitkan minat dan motivasi belajar yang selanjutnya akan mengoptimalkan aktivitas belajar peserta didik (Movitaria \& Shandra, 2020). Materi ekonomi yang dipelajari pada kelas XII berfokus kepada materi akuntansi, materi ini adalah materi yang baru, sehingga pemahaman peserta didik terhadap konsep akuntansi masih sangat minim, disamping itu antusias mereka untuk belajarpun masih sangat kurang, sehingga untuk mengatasi permasalahan ini peneliti tertarik untuk menggunakan media pembelajaran monopoli akuntansi yang telah dirancang sebelumnya. Sugito, (2013) menyatakan bahwa media Monopoli akuntansi merupakan permainan adopsi dari permainan monopoli yang telah ada namun dikombinasikan dengan akun-akun yang terdapat pada perusahaan dan transaksi yang terjadi pada perusahaan. Permainan ini merupakan media yang sangat menarik untuk melatih kemampuan mereka dalam berpikir dan berkreasi untuk mengelola keuangan, sehingga mereka seolah-olah mengaplikasikan langsung ilmu yang telah mereka dapatkan dalam pembelajaran akuntansi.

\section{METODE PENELITIAN}

Jenis penelitian ini adalah penelitian praktik dalam bentuk penelitian tindakan kelas (Classroom Action Research). Adapun yang menjadi subjek dalam penelitian ini adalah peserta didik kelas XII. MIPA 2 di SMA Negeri 10 Padang. Kelas XII. MIPA II berjumlah 32 orang terdiri dari 20 peserta didik perempuan dan 12 peserta didik laki-laki. Objek yang diteliti adalah pembelajaran akuntansi dengan menggunakan model pembelajaran inkuiri terbimbing sebagai upaya meningkatkan aktivitas dan hasil belajar akuntansi peserta didik. Jenis penelitian ini adalah penelitian tindakan kelas (classroom action research) yang bertujuan untuk meningkatkan aktivitas dan hasil belajar peserta didik. Penelitian tindakan kelas ini dilakukan beberapa siklus tindakan berurutan, informasi dari siklus yang terdahulu sangat menentukan siklus berikutnya. Arikunto, (2021) penelitian tindakan kelas terdiri dari empat komponen, yaitu: 1) Perencanaan, 2) Pelaksanaan, 3) Pengamatan, 4) Refleksi. Instrumen penelitian yang digunakan untuk mengumpulkan data dalam penelitian ini adalah tes berbentuk pilihan ganda yaitu berupa pretest dan posttest serta observasi aktivitas peserta didik selama kegiatan pembelajaran berlangsung. Dalam penelitian ini ada dua jenis data yang digunakan yaitu data kualitatif dan data kuantitatif.

\section{HASIL DAN PEMBAHASAN}

Pada tahap perencanaan, guru bidang studi dan peneliti mengadakan diskusi tentang pelaksanaan penelitian tindakan kelas, membuat rencana pelaksanaan model pembelajaran inkuiri terbimbing pada kompetensi dasar tahap pencatatan pada siklus akuntansi perusahaan dagang, sub materi bukti transaksi. Peneliti menyiapkan lembar observasi aktivitas peserta didik, menyiapakan lembar kerja dan menyiapkan tes yang akan diberikan kepada peserta didik. Pada tahap ini, guru melaksanakan perannya sebegai pengajar dengan menerapkan menerapkan model pembelajaran inkuiri terbimbing yang sudah dirancang dalam rencana pelaksanaan pembelajaran. 
Pada awal pertemuan, guru menjelaskan kepada peserta didik mengenai tujuan dan kompetensi dasar yang akan dicapai peserta didik setelah mengikuti proses pembelajaran ini. Selanjutnya, guru melaksanakan test awal (pretest) untuk mengetahui pemahaman awal peserta didik terhadap materi bukti transaksi. Setelah test selesai, guru menjelaskan tentang penerapan model pembelajaran inkuiri terbimbing kemudian dilanjutkan dengan memberikan bahan ajar yang sesuai dengan rencana pelaksanaan pembelajaran.

Guru membagi peserta didik ke dalam beberapa 8 kelompok dimana masing-masing kelompok terdiri atas 4 peserta didik. Setiap peserta didik di dalam kelompok diberikan lembar kerja dimana pada lembar kerja tersebut terdapat beberapa aktivitas yang berhubungan dengan materi pelajaran. Pada pertemuan sebelumnya, peserta didik sudah disuruh untuk mencari bukti transaksi minimal 5 perindividu (kwitansi, nota kontan, cek, memo, faktur penjualan, faktur pembelian). Setiap peserta didik harus mengklasifikasi ciri-ciri masing-masing bukti transaksi dan menempelkan bukti transaksi pada lembar kerja yang tersedia, selanjutnya, peserta didik menganalisis data yang telah terkumpul untuk dibuat analisis transaksi baik dari segi pembuat bukti transaksi maupun dari segi penerima bukti transaksi. Pada aktivitasnya, peserta didik diminta untuk mendiskusikan transaksi-transaksi yang harus dibuat analalisis transaksinya. Pada tahap berikutnya, masing - masing kelompok dipersilahkan untuk mempresentasikan hasil diskusi mereka. Setelah selesai, guru kemudian memberikan penjelasan mengenai materi dan membahas soal yang diberikan.

Pada akhir tindakan siklus I, guru memberikan test formatif (postest). Saat test ini berlangsung, setiap peserta didik mengerjakan test secara individu. Hasil test ini menjadi penentu apakah peserta didik tersebut berhasil atau tidak selama penerapan model pembelajaran inkuiri terbimbing. Data hasil belajar pada materi bukti transaksi terdiri dari hasil belajar sebelum penerapan model pembelajaran inkuiri terbimbing atau pretest, dimana tidak seorangpun yang lulus pada tes ini, karena memang peserta didik belum mempelajari materi $(0 \%)$ dengan nilai rata-rata 26 dan hasil belajar setelah penerapan model pembelajaran inkuiri terbimbing atau post test dengan hasil 10 peserta didik (31\%) yang tuntas dengan rata-rata 63.

Pada penelitian tindakan kelas ini, pengamatan dilakukan oleh peneliti sendiri dan dibantu oleh rekan sejawat serta guru pamong mata pelajaran ekonomi. Pada pertemuan pertama, peneliti memberi tes awal dan dilanjutkan dengan penerapan model pembelajaran inkuiri terbimbing. dengan membagi peserta didik ke dalam 8 kelompok untuk melakukan aktivitas kerja. Dari kegitan ini, peneliti mengamati bahwa peserta didik masih kurang memperhatikan arahan guru, kurang memahami materi sehingga kurang aktif dalam kegiatan diskusi.

Pada pertemuan kedua, peserta didik melanjutkan kegiatan diskusi dan menyelesaikan hasil kerja kemudian melakukan presentasi hasil diskusi. Peneliti melakukan pengamatan terhadap aktivitas peserta didik selama proses pembelajaran berlangsung, dan dilakukan penilaian dalam lembar observasi aktivitas peserta didik. Pada siklus I ini terdapat 3 peserta didik (9\%) yang berada pada kreteria tidak aktif, 19 peserta didik (59\%) yang berada pada kreteria kurang aktif, 4 peserta didik (13\%) yang berada pada kreteria cukup aktif, 4 peserta didik (13\%) yang berada pada kreteria aktif, dan 2 peserta didik $(6 \%)$ yang berada pada kreteria sangat aktif. Dengan hasil tersebut dapat terlihat bahwa hasil ketuntasan klasikal hanya 19\% yaitu hanya 6 peserta didik yang memenuhi kategori aktif dengan skor minimal 23, yang terdiri dari 4 peserta didik (13\%) yang berada pada kreteria aktif, dan 2 peserta didik $(6 \%)$ yang berada pada kreteria sangat aktif.

Pada pengamatan ini, peneliti melihat bahwa peserta didik masih belum terbiasa dengan penerapan model pembelajaran inkuiri terbimbing. Hal ini dapat dilihat dari peserta didik yang masih kurang semangat mengikuti kegiatan belajar, peserta yang masih kurang paham dengan materi akuntansi, peserta didik masih ragu-ragu dalam bertanya dan mengeluarkan pendapat serta kejenuhan yang dialami peserta didik selama pembelajaran, sehingga keakftifan dalam belajar masih belum maksimal.

Pada Siklus II, Hasil perolehan pada siklus I setelah dilakukan refleksi masih belum memenuhi Ketuntasan Belajar Minimal secara klasikal yaitu minimal $80 \%$ peserta didik harus memperoleh nilai $\geq 80$. Hasil observasi juga masih jauh dari yang diharapkan. Untuk itu peneliti dan guru bidang studi perlu 
pembahasan dan mengadakan perbaikan pembelajaran di siklus II yaitu lebih mempersiapkan pelaksanaan model inkuiri terbimbing pada kompetensi dasar tahap pencatatan pada siklus akuntansi perusahaan jasa dengan sub materi jurnal umum, mempersiapkan perangkat-perangkat pembelajaran, menyiapkan media pembelajaran, dimana kali ini yang digunakan adalah monopoli akuntansi yang lebih meningkatkan kreativitas peserta didik dalam belajar. Selain itu guru lebih memotivasi peserta didik dan memberi penghargaan sehingga peserta didik lebih aktif dalam pembelajaran.

Pada siklus II, kegiatan pembelajaran berlangsung sesuai dengan rencana pelaksanaan pembelajaran. Pelaksanaan siklus II, guru menyiapkan media yang berbeda dan lebih memeperhatikan kegiatan pembelajaran terhadap evaluasi dan refleksi dengan harapan ada peningkatan kemampuan belajar peserta didik agar sesuai dengan ketuntasan belajar minimal (KBM).

Guru membagi peserta didik ke dalam beberapa 8 kelompok dimana masing-masing kelompok terdiri atas 4 peserta didik. Setiap kelompok diberikan 1 set papan monopoli yang telah dicetak, lengkap dengan dadu, pion, pernak pernik, peraturan, uang monopoli serta kartu kesempatan dan dana umum. Setiap peserta didik akan mendapatkan lembar kerja yang berisi format jurnal umum, dimana setiap peserta didik harus mencatat setiap transaksi yang terjadi kedalam jurnal umum. Tentu hal ini memerlukan tingkat analisa yang lebih tinggi, dan kreatifitas yang tinggi karena setiap peserta didik akan melakukan pencatatan berbeda-beda, tergantung dari aktivitas masing-masing kelompok monopoli. Pada sisi lain peserta didik juga dituntut untuk berpikir untuk menggunakan sumber daya yang ada agar dapat memperoleh kekayaan sebanyak-banyaknya dari aset yang tersedia. Sambil belajar peserta didik bisa bermain, sehingga kejenuhan dapat diatasi dan otomatis aktivitas pembelajaran dapat dioptimalkan. Setelah permainan berakhir, guru kemudian memberikan penjelasan materi dan peserta didik dipersilahkan mempresentasikan hasil dari kegiatan yang telah dilakukan dan menginformasikan kekayaan yang terkumpul. Bagi kelompok yang memiliki kekayaan paling banyak akan diberikan hadiah berupa nilai plus 2 untuk tambahan nilai ulangan.

Setelah kegiatan ini berakhir, maka pada pertemuan 4 guru akan memberikan test (post test) kepada peserta didik untuk mengetahui sejauh mana perubahan yang terjadi setelah penerapan model pembelajaran inkuiri terbimbing pada siklus II. Hasil perolehan hasil belajar peserta didik pada siklus II mencapai $84 \%$ yaitu 27 peserta didik yang tuntas belajar dengan nilai rata - rata 83. Sehingga mengalami peningkatan sebesar 53\% dari siklus I.

Sama halnya dengan siklus I, pada siklus ini pengamatan juga dilakukan pada saat kegiatan pembelajaran berlangsung. Pada kegiatan pembelajaran, aktivitas peserta didik terlihat lebih produktif. Peserta didik juga lebih semangat, aktif dan kreatif dalam kegiatan pembelajaran. Pada siklus II ini tidak terdapat peserta didik yang berada pada kreteria tidak aktif dan kurang aktif. 2 peserta didik (6\%) berada pada kreteria cukup aktif, 17 peserta didik (53\%) berada pada kreteria aktif, dan 13 peserta didik (40\%) berada pada kriteria sangat aktif. Dengan hasil tersebut dapat terlihat bahwa hasil ketuntasan klasikal sebesar $94 \%$ atau 30 peserta didik yang tergolong kategori aktif yang terdiri dari 17 peserta didik (53\%) yang berada pada kreteria aktif, dan 13 peserta didik (41\%) yang berada pada kreteria sangat aktif. Dari siklus I yaitu 19\% peserta didik yang aktif, pada siklus II menjadi 94\%, sehingga dari siklus I ke siklus II mengalami peningkatan aktivitas belajar sebesar 75\%. Hasil tersebut dapat menggambarkan bahwa peserta didik secara umujm telah mampu mengembangkan potensi yang dimiliki dengan maksimal. Hal ini sejalan dengan pendapat Sardiman, (2012) yang mengungkapkan bahwa aktivitas belajar itu merupakan potensi atau kemampuan untuk melakukan usaha dalam rangka mengembangkan dirinya agar lebih maju, sehingga dapat mencapai hasil belajar yang baik.

\section{KESIMPULAN}

Berdasarkan hasil analisis data observasi dan tes hasil belajar penerapan model pembelajaran inkuiri terbimbing pada pembelajaran akuntansi di Kelas XII. MIPA 2 SMA Negeri 10 Padang dapat disimpulkan 
hasil belajar peserta didik dapat disimpulkan bahwa penerapan model pembelajaran inkuiri terbimbing dapat meningkatkan aktivitas belajar peserta didik. Kemampuan peserta didik dalam menemukan data dengan mengumpulkan bukti transaksi, verifikasi data, pengumpulan data melalui eksperimen, pengorganisasian data dan analisis data melalui diskusi dapat merangsang aktivitas belajar peserta didik secara menyeluruh sehingga proses pembelajaran dapat berjalan lebih optimal. Hasil penelitian memperlihatkan bahwa terjadi peningkatan aktivitas belajar peserta didik dari siklus I ke siklus II. Hal ini menunjukkan bahwa pembelajaran dengan menerapkan model pembelajaran inkuiri terbimbing dapat menuntun peserta didik menjadi lebih aktif dan bersemangat dalam belajar.

\section{DAFTAR PUSTAKA}

Aini, F., Efendi, Y., \& Movitaria, M. A. (2021). Peningkatan Aktivitas Dan Hasil Belajar Paidbp Siswa Kelas Iv Sekolah Dasar Melalui Penggunaan Model Discovery Learning. Attadrib: Jurnal Pendidikan Guru Madrasah Ibtidaiyah, 4(2), 55-61.

Arikunto, S. (2021). Penelitian Tindakan Kelas: Edisi Revisi. Bumi Aksara.

Darlis, N., \& Movitaria, M. A. (2021). Penggunaan Model Assure Untuk Meningkatkan Hasil Belajar Tematik Terpadu Di Sekolah Dasar. Jurnal Basicedu, 5(4), 2363-2369.

Darmadi. (2017). Pengembangan Model Dan Metode Pembelajaran Dalam Dinamika Belajar Siswa. In Deepublish.

Diani, R., Ifana, A., \& Saregar, A. (2016). Perbandingan Model Pembelajaran Problem Based Learning Dan Inkuiri Terbimbing Terhadap Kemampuan Berpikir Kritis Peserta Didik. Jurnal Penelitian Pembelajaran Fisika, 7(2), 147-155.

Djo, K. (2021). Penerapan Media Permainan Ular Tangga Untuk Meningkatkan Hasil Belajar Ips Siswa Kelas V:(Studi Pada Sdk Kekawii Kabupaten Ende). Ekspektasi: Jurnal Pendidikan Ekonomi, 6(1), 32-38.

Jamin, H. (2018). Upaya Meningkatkan Kompetensi Profesional Guru. At-Ta'dib: Jurnal Ilmiah Prodi Pendidikan Agama Islam, 19-36.

Latiana, L., Samsudi, S., Sugiyo, S., \& Slameto, S. (2018). Developing Collaboration-Based Supervision Model To Enhance The Professionalism Of Early Childhood Education Teachers. The Journal Of Educational Development, 6(1), 132-143.

Lovisia, E. (2018). Pengaruh Model Pembelajaran Inkuiri Terbimbing Terhadap Hasil Belajar. Science And Physics Education Journal (Spej). Https://Doi.Org/10.31539/Spej.V2i1.333

Movitaria, M. A. (2017). Pengaruh Penerapan Pembelajaran Brain Based Learning Approach Dan Motivasi Terhadap Hasil Belajar Ipa Siswa Kelas V Gugus Iv Kecamatan Padang Utara. Universitas Negeri Padang.

Movitaria, M. A., \& Shandra, Y. (2020). Improving Teachers' Abilities In Video Based Learning By Using Microsoft Powerpoint Application Through Workshop. Jurnal Basicedu, 4(4), 1423-1428.

Mulyana, E. H. (2010). Guru Berkualitas: Profesional Dan Cerdas Emosi. Jurnal Saung Guru.

Nurudin, N. (2020). Pengaruh Persepsi Kompetensi Guru Dan Persepsi Komunikasi Interpersonal Guru Terhadap Prestasi Belajar. Prosiding Seminar Nasional Magister Psikologi ....

Pribadi, R. B. A. (2017). Media Dan Teknologi Dalam Pembelajaran. Jakarta: Kencana.

Sardiman. (2012). Interaksi Dan Motiovasi Belajar Dan Mengajar. Rajawali Press.

Sugito, C. S. J. D. (2013). Penerapan Strategi Pembelajaran Inkuiri Untuk Meningkatkan Hasil Belajar Melukis Siswa Kelas Xi Akuntansi 1 Smknegeri 1 Takengon Tahun Ajaran 20012/2013. Gorga : Jurnal Seni Rupa. Https://Doi.Org/10.24114/Gr.V2i1.1028 
699 Penerapan Model Pembelajaran Inkuiri Terbimbing untuk Meningkatkan Hasil Belajar Siswa - Yosi Shandra, Mega Adyna Movitaria

DOI: https://doi.org/10.31004/basicedu.v6i1.2006

Wenno, I. H., Esomar, K., \& Sopacua, V. (2016). Analisis Kesulitan Belajar Dan Pencapaian Hasil Belajar Siswa Melalui Strategi Pembelajaran Inkuiri. Jurnal Cakrawala Pendidikan. Https://Doi.Org/10.21831/Cp.V35i3.10706 